\title{
Impact of early-life diet on long-term renal health
}

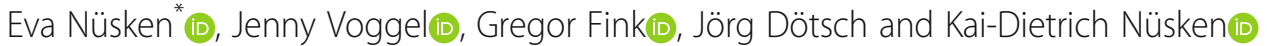

\begin{abstract}
In the last years, great advances have been made in the effort to understand how nutritional influences can affect long-term renal health. Evidence has accumulated that maternal nutrition before and during pregnancy and lactation as well as early postnatal nutrition is of special significance. In this review, we summarize epidemiologic and experimental data on the renal effects of perinatal exposure to energy restriction, low-protein diet, high-fat diet, high-fructose diet, and high- and low-salt diet as well as micronutrient deficiencies. Interestingly, different modifications during early-life diet may end up with similar sequelae for the offspring. On the other hand, molecular pathways can be influenced in opposite directions by different dietary interventions during early life. Importantly, postnatal nutrition significantly modifies the phenotype induced by maternal diet. Sequelae of altered macro- or micronutrient intakes include altered nephron count, blood pressure dysregulation, altered sodium handling, endothelial dysfunction, inflammation, mitochondrial dysfunction, and oxidative stress. In addition, renal prostaglandin metabolism as well as renal AMPK, mTOR, and PPAR signaling can be affected and the reninangiotensin-aldosterone system may be dysregulated. Lately, the influence of early-life diet on gut microbiota leading to altered short chain fatty acid profiles has been discussed in the etiology of arterial hypertension. Against this background, the preventive and therapeutic potential of perinatal nutritional interventions regarding kidney disease is an emerging field of research. Especially individuals at risk (e.g., newborns from mothers who suffered from malnutrition during gestation) could disproportionately benefit from well-targeted dietary interventions.
\end{abstract}

Keywords: Early-life diet, Maternal nutrition, Postnatal nutrition, Kidney development, Perinatal diet modification, Malnutrition, Renal programming, Kidney disease

\section{Introduction}

Animal studies on the influence of maternal nutrition on offspring kidney development can be found as early as in the 1960s [1]. First epidemiologic studies discussing the influence of early-life nutrition on risk of disease in adult life were published in the 1970s [2, 3]. Since then, great advances have been made in the effort to understand how nutritional influences during specific windows of development can affect long-term renal health. In this review, we summarize current knowledge of how energy intake and dietary composition of macronutrients and micronutrients during perinatal development act upon renal health (for an overview see Fig. 1).

\footnotetext{
* Correspondence: eva.nuesken@uk-koeln.de

Department of Pediatrics and Adolescent Medicine, Medical Faculty and University Hospital Cologne, University of Cologne, Kerpener Str. 62, 50937 Cologne, Germany
}

\section{Energy restriction}

Experimental studies on the effect of energy restriction are challenging to interpret since total energy restriction necessarily goes along with restriction of a varying amount and combination of macronutrients in most settings. In epidemiological studies, it is not even possible to define the exact composition of the diet. Despite these limitations, some interesting studies are hinting at possible effects of total energy restriction during early life on long-term renal health. Thus, individuals exposed to the Dutch Famine 1944/1945 during midgestation had an elevated risk of suffering from microalbuminuria during their fifth and sixth decade [4]. In Chinese women, exposure to the Chinese Famine 1959-1961 during fetal or early life was associated with an increased risk of proteinuria three decades later [5].

\section{Springer Open}

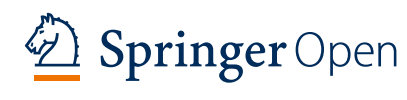

(c) The Author(s). 2020 Open Access This article is licensed under a Creative Commons Attribution 4.0 International License, which permits use, sharing, adaptation, distribution and reproduction in any medium or format, as long as you give appropriate credit to the original author(s) and the source, provide a link to the Creative Commons licence, and indicate if changes were made. The images or other third party material in this article are included in the article's Creative Commons licence, unless indicated otherwise in a credit line to the material. If material is not included in the article's Creative Commons licence and your intended use is not permitted by statutory regulation or exceeds the permitted use, you will need to obtain permission directly from the copyright holder. To view a copy of this licence, visit http://creativecommons.org/licenses/by/4.0/. 


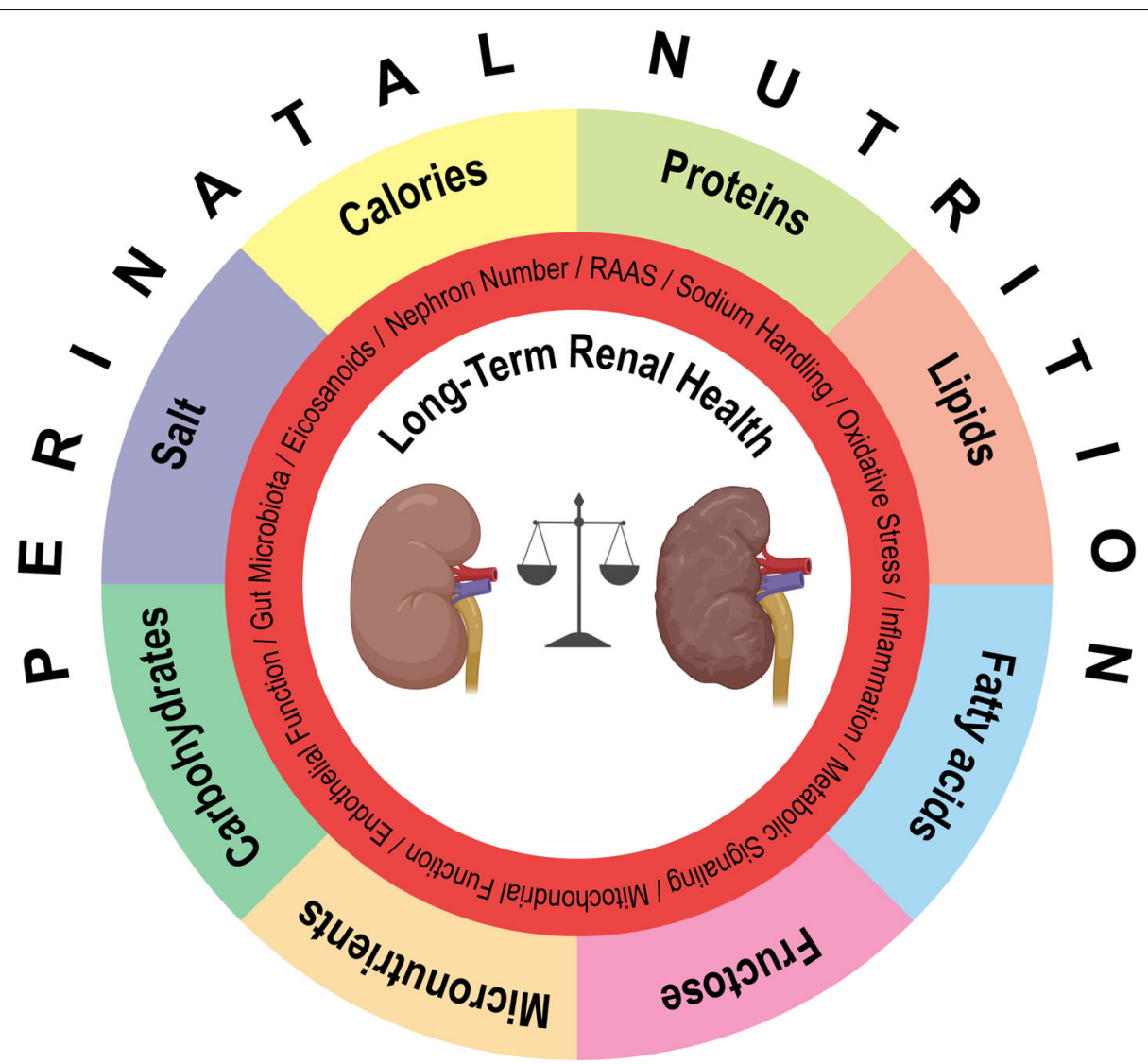

Fig. 1 Schematic overview on the interplay between macro- and micronutrients and important developmental patterns/mechanisms involved in renal disease. RAAS, renin-angiotensin-aldosterone system. The figure was created using BioRender (www.biorender.com)

Rat offspring exposed to $50 \%$ maternal nutrient restriction throughout pregnancy compared to control ad libitum intake clinically developed reduced renal function, arterial hypertension, and increased proteinuria. Mechanistically, this was linked to reduced nephron count, endothelial dysfunction, oxidative stress, and RAAS dysregulation in adulthood [6, 7]. During kidney development, there was evidence for impaired ureteric bud branching and downregulation of proliferative pathways (ERK, p38 MAPK, Akt, PI3K, mTOR) in utero [8] and dysregulation of genes involved in PPAR signaling and glutathione metabolism during early life [9].

In sheep, periconceptional undernutrition, twin pregnancy, and maternal nutrient restriction to $50 \%$ of requirements during specific periods of kidney development were associated with altered gene expression of receptors regulating kidney growth in the offspring $[10,11]$. Interestingly, animals exposed to $50 \%$ maternal nutrient restriction showed less pronounced renal inflammation when they were challenged by a high-fat diet postnatally [12].

In baboons, maternal nutrient restriction to $70 \%$ of controls during early to midgestation was associated with impaired tubule development, alterations in fetal renal mTOR signaling, and altered mitochondrial gene expression [13-15].

\section{Macronutrients}

Protein

Low-protein nutrition during gestation is probably the most widely used experimental setup to study the influence of early nutrition on adult renal health. Starting in the 1990s, it could first be shown in rats that low-protein diet throughout gestation results in reduced nephron count and arterial hypertension [16-19], pronounced deterioration of renal function with increasing age [20,21], and increased susceptibility towards second hits [17, 22]. A multitude of molecular alterations mutually affecting each other has been identified in low-protein studies performed in rats in the meantime. Thus, quantitative and qualitative alterations of the reninangiotensin-aldosterone system [18, 23-30], altered tubular salt handling [29, 31-35], and salt sensitivity of blood pressure [32, 36], as well as dysbalanced glucocorticoid metabolism [37], are important endocrine sequelae. Furthermore, there is evidence for enhanced inflammation [30] and oxidative stress $[29,30,38]$ as well as altered prostaglandin 
metabolism [39] and endothelial [21] and mitochondrial dysfunction [40]. Dysregulation of AMPK, PPAR, and mTOR pathways may predispose towards obesity-associated kidney damage [41].

Importantly, it has been shown that postnatal nutrition significantly modifies the phenotype induced by maternal low-protein diet [42]. Thus, fostering low-protein pups to dams fed a control diet with normal protein content partially mitigates renal sequelae [43]. Conversely, healthy control pups raised in litters of 6-8 individuals by foster dams receiving low-protein diet developed arterial hypertension [44]. In another study, rat dams were protein-restricted during lactation only and litters were reduced to six males. Their offspring developed reduced nephron count, hyperfiltration, proteinuria, and altered salt handling associated with a dysregulation of angiotensin II signaling at 60 days of age [32]. In addition, both the phenotype and the molecular alterations are sex-dependent [37]. In some studies, it was shown that effects might even be transferred to subsequent generations [45].

Although most studies were performed in rats, similar results were published in mice [46, 47] and sheep [43, 48, 49]. Interestingly, maternal high-protein diet during gestation had no effect on renal morphology or function in the offspring [50].

\section{Lipids}

Dietary lipids play a role in chronic kidney disease [51]. During kidney development, most studies have focused on the effect of excess dietary lipids. Conflicting results from these studies may rely on the finding that the fatty acid composition of dietary lipids has a major impact [52-54]. In addition, postnatal nutrition modifies the phenotype [55] and the dietary content of fructose should be taken into account since high-fat diet and Western-style diet have differential effects. Thus, studies influencing the effect of a "high-fat" diet are difficult to compare since the specific dietary interventions used to vary a lot.

In rats, maternal high-fat diet during gestation and lactation was associated with persisting upregulation of the renin-angiotensin system in adipose and renal tissue, increased oxidative stress markers, dysregulation of sodium transporters and circadian clock markers, and the development of arterial hypertension in adult life [5658]. Perinatally, high-fat offspring presented with increased glomerular number which was no longer retraceable at 9 months of age [59]. Exposure to a modified high-fat diet rich in lipids containing saturated, mono-unsaturated, and n- 6 polyunsaturated fatty acids in utero and until weaning resulted in vascular dysfunction, reduced renal $\mathrm{Na}+, \mathrm{K}+-\mathrm{ATPase}$ and reduced renin activity at 6 to 12 months of age. Renal stereology was not affected [60]. Exposure to both maternal and post- weaning high-fat diet (HF/HF) resulted in differentially composed gut microbiota and altered fetal concentrations of short chain fatty acids, which are known to affect blood pressure levels [61]. Treatment of HF/HF animals with the antioxidant resveratrol during young adult life prevented the development of arterial hypertension [62]. In another HF/HF study, tubular injury, impaired renal function, and increased expression of inflammatory markers were observed. These sequelae could be mitigated by $n-3$ fatty acid supplementation in the HF/HF group [54].

In mice, our group performed proteomic analyses of fetal kidneys shortly before birth. Proteins differentially expressed by maternal high-fat diet could be linked to eicosanoid metabolism, H2S-synthesis, transcription/ translation, mitochondrial processes, and membrane remodeling [63]. In another mouse study, high-fat diet during gestation and lactation was associated with increased renal leptin signaling and decreased renal Akt/ AMPK signaling at 3 weeks of age. Interestingly, at 10 weeks of age, leptin signaling was decreased in these animals [64]. Maternal high-fat diet restricted to the lactation period only had similar metabolic alterations in the offspring at 3 weeks of age but no effects at 10 weeks [64]. A study that combined maternal and post-weaning high-fat diet (HF/HF) resulted in albuminuria and increased renal triglyceride accumulation of the offspring going along with upregulation of markers indicative of inflammation, fibrosis, and oxidative stress. Experimentally induced overexpression of Sirtuin 1 partially mitigated these effects [65].

Remarkably, not only maternal but also paternal highfat diet before mating can induce renal sequelae in the offspring. Thus, paternal high-fat diet in rats was associated with increased renal triglyceride accumulation and signs of tubular damage in adult male offspring, although in utero and postnatal conditions did not differ between groups [66]. Similar to sequelae seen in lowprotein models, effects of high-fat diet in the offspring are sex-dependent [58].

\section{Fatty acids}

In the Amsterdam Born Children and their Development $(A B C D)$ study, low maternal serum concentrations of n-3 fatty acids (FA) and C20:3 n-6 (Dihomo- $\gamma$-linolenic acid, DGLA), and high maternal serum concentrations of trans fatty acids and C20:4 n-6 (arachidonic acid, ARA) were associated with an increased risk of giving birth to small for gestational age (SGA) infants [67]. In line with this, an Indian study reported a negative correlation of maternal ARA plasma concentrations and a positive correlation of maternal n-3 FA plasma concentrations with birth weight [68]. These findings are relevant for the kidney since epidemiological studies 
have shown that being small for gestational age is associated with an elevated risk of decreased renal function in young adulthood [69] and adverse course of glomerulopathies [70].

Postnatally, docosahexaenoic acid (DHA) concentrations in breast milk correlate with phospholipid FA composition of infant erythrocytes [71]. Dietary supplementation of the $\mathrm{n}-3$ fatty acid DHA to the mother was shown to be an effective strategy to increase DHA breastmilk concentrations and increase omega-3 fatty acid availability during the neonatal period [71, 72]. In a mouse model, variation of dietary $n-3 / n-6$ FA ratios during gestation and weaning was reflected in variation of kidney phospholipid FA composition [73]. Thus, perinatal availability of FA may have long-lasting consequences for the susceptibility towards kidney disease, since glycerophospholipid composition of organ membranes plays a role in a variety of pathologic conditions including cancer [74].

\section{Western-style diet}

Perinatal and post-weaning Western-style diet (containing an increased amount of fat and fructose) in rats resulted in albuminuria, glomerulosclerosis, and tubulointerstitial fibrosis in adult life [55, 75] going along with an increased expression of inflammatory markers $[75,76]$.

\section{Fructose}

High-fructose intake during gestation and lactation was associated with the development of arterial hypertension and increased expression of oxidative stress markers in rat offspring [77]. At 2 weeks of age, transcriptome analysis from renal rat tissue hinted at alterations of peroxisome proliferator-activated receptor (PPAR) signaling and glutathione metabolism [9]. Inhibition of soluble epoxide hydrolase in the offspring during the early postnatal period prevented the development of arterial hypertension. Mechanistically, this might rely on a regulatory effect of the arachidonic acid pathway leading to, e.g., an increase of vasodilatory epoxyeicosatrienoic acids (EETs) [77]. In another rat study, arterial hypertension induced by maternal high-fructose diet was attributed to dysregulation of gut microbiota as well as serum short chain fatty acids and their receptors in the offspring [78].

\section{Micronutrients}

Human studies on the effect of micronutrients during early life were mainly performed in populations with a high percentage of suspected malnutrition. Thus, in a large randomized trial in Nepal, it could be shown that supplementation of the daily allowance of 15 minerals and vitamins in pregnant women was associated with a slightly lower blood pressure of their children at 2.5 years [79]. However, in a follow-up analysis studying Nepalese children at 6-8 years, no effect of maternal micronutrient supplementation on blood pressure levels could be demonstrated. Instead, there was evidence that supplementation of folic acid or a combination of folic acid, iron, and zinc during pregnancy reduced the prevalence of microalbuminuria in this age group [80]. In a similar study from Bangladesh, maternal micronutrient supplementation (daily allowance of 15 micronutrients minerals and vitamins) was even associated with a marginally higher diastolic blood pressure at 4.5 years of age [81].

Looking at single supplements, data is available for vitamin $\mathrm{A}$, iron, and zinc. Thus, there was a positive correlation between maternal serum retinol concentrations and newborn kidney size at birth in a small cohort study from Egypt [82]. This would be in line with a study from rats, in which reduced vitamin A availability in utero induced low nephron count [83]. Similarly, iron restriction in rats caused a reduction of glomerular number in adult offspring [84]. In other studies, it could be shown that exposure to iron deficiency during gestation postponed nephrogenesis [85] and predisposed towards high-saltinduced arterial hypertension and mitochondrial dysfunction [86]. Deficiency during gestation was clinically associated with the development of arterial hypertension and decreased renal function of the offspring in experimental models. Histological and molecular analyses provided evidence for reduced nephron count and increased oxidative stress $[87,88]$.

\section{Salt}

Studies on "high salt" and "low salt" diet during gestation and early postnatal development are highly variable regarding the exact amount of salt given.

In rats, both high- (3.0\%) and low (0.07\%)-salt diets during gestation and lactation were associated with arterial hypertension in adult male offspring at 5 months of age. Mechanistically, this was linked to low nephron count [89]. Similarly, a maternal diet containing 4\% $\mathrm{NaCl}$ during gestation and lactation was associated with elevated blood pressure in male offspring in young adulthood. Interestingly, both male and female offspring were hypernatremic at this age despite being fed regular chow which was attributed to chronically increased corticosterone levels and altered gastrointestinal sodium handling [90]. A diet containing extremely high (8.0\%) $\mathrm{NaCl}$ content during gestation (compared to $1.3 \%$ in controls) was shown to induce lower basal plasma renin activity, lower serum aldosterone, and reduced renal renin gene expression in male offspring at 12 weeks of age while blood pressure was elevated after high-salt challenge only [91]. Another study using the same salt exposure $(8.0 \%)$ reported increased renal $\mathrm{AT}_{1}: \mathrm{AT}_{2}$-receptor and increased ACE:ACE2 expression ratios in the 
offspring [92]. In a study that supplemented salt not via food but via drinking water $(1 \% \mathrm{NaCl})$ during pregnancy and lactation, male offspring showed alterations in the expression and activity of renal sodium transporters, increased infiltration with macrophages, increased deposition of collagen, and decreased $\mathrm{AT}_{2}$-receptor expression [93]. In the same setting $(1 \% \mathrm{NaCl}$ via drinking water), the development of arterial hypertension could be shown and next-generation RNA sequencing was performed to identify candidate genes for renal programming. In total, 272 genes were differentially expressed in highsalt offspring compared to controls, including genes belonging to clusters of cell adhesion molecules and complement and coagulation cascades [9].. Sheep offspring from mothers either exposed to a high-salt diet (14\% compared to $2 \% \mathrm{NaCl}$ ) or fed saltbush (compared to dry pasture) during gestation had lower basal renin activity than their controls. In saltbush offspring, lower renin activity even persisted during post-weaning salt overload [94, 95].

\section{Molecular mechanisms}

Interestingly, different modifications during early-life diet may end up with similar sequelae for the offspring. On the other hand, molecular pathways can be influenced in opposite directions by different dietary interventions during early life. In Table 1, we present an overview of early-life dietary modifications, known molecular effects on kidney development, and renal outcome.

\section{Secondary prevention and therapeutic potential of nutritional interventions}

In recent years, there is growing interest in the therapeutic potential of nutritional interventions. Especially individuals at risk could disproportionately benefit from well-targeted dietary interventions. However, the number of dietary interventions to prevent renal disease is still limited.

In a human study from rural Nepal, supplementation of folic acid or a combination of folic acid, iron, and zinc during pregnancy reduced the risk of microalbuminuria in childhood [80]. Similarly, supplementation of selenium, folate, vitamin $\mathrm{C}$, and vitamin $\mathrm{E}$ during $50 \%$ food restriction in rats prevented the development of arterial hypertension and endothelial dysfunction in the offspring. However, it did not protect against reduced glomerular number and impaired renal function in adulthood [6]. In rats exposed to low-protein diet during gestation, maternal supplementation of glycine prevented the development of arterial hypertension [96] and a single dose of vitamin A during midgestation prevented low nephron count [97]. However, in preterm but otherwise healthy baboons, early postnatal administration of vitamin A was not able to stimulate nephrogenesis [98]. Regulation of maternal gut microbiota by either probiotic or prebiotic strategies during maternal high-fructose diet prevented the development of arterial hypertension in the offspring. This effect was attributed to a regulation of gut microbiota as well as normalization of short chain fatty acids and their receptors in the offspring [70].

Taken together, these studies encourage further research on the preventive potential of dietary interventions. The better we learn to understand why an individual is at risk to develop kidney disease, the better we will be able to develop targeted nutritional interventions. So far, a couple of risk factors have been identified. In addition to adverse intrauterine conditions [99], ethnic background has been shown to influence renal function [100] and blood pressure [101] in childhood

Table 1 Overview of early-life dietary modifications and known molecular effects

\begin{tabular}{|c|c|}
\hline Morphological/molecular effect & Early-life dietary modification \\
\hline Reduced nephron count & $\begin{array}{l}\text { Energy restriction }[6,7] \text {, low-protein diet }[16,17,19] \text {, high- or low-salt diet }[89], \text { maternal deficien- } \\
\text { cies in vitamin A [83], iron [84], or zinc }[87]\end{array}$ \\
\hline $\begin{array}{l}\text { Dysregulation of the renin-angiotensin- } \\
\text { aldosterone system (RAAS) }\end{array}$ & $\begin{array}{l}\text { Energy restriction [7], low-protein diet }[18,23-27,30] \text {, high-fat diet [56], and high-salt diet [91-93, } \\
95]\end{array}$ \\
\hline $\begin{array}{l}\text { Altered expression and/or activity of renal sodium } \\
\text { transporters }\end{array}$ & Low-protein diet $[29,31-35]$, high-fat diet $[58,60]$, and high-salt diet $[93]$ \\
\hline Oxidative stress & $\begin{array}{l}\text { Energy restriction }[6,7] \text {, low-protein diet }[29,30,38] \text {, high-fat diet }[56,58,62,65] \text {, and high- } \\
\text { fructose diet }[77]\end{array}$ \\
\hline Inflammation & $\begin{array}{l}\text { Low-protein diet }[30], \text { high-fat diet }[54,65,75,76], \text { Western-style diet (high fat/high fructose) }[75 \text {, } \\
\text { 76], and high-salt diet [93] }\end{array}$ \\
\hline $\begin{array}{l}\text { Dysregulated metabolic signaling, (e.g., AMPK, } \\
\text { mTOR, or PPAR signaling) }\end{array}$ & Energy restriction $[8,9,13-15]$, low-protein diet [41], and high-fat diet [64] \\
\hline Mitochondrial dysfunction & Energy restriction [13-15], low-protein diet [40], and high-fat diet [63] \\
\hline Endothelial dysfunction & Energy restriction $[6,7]$, low-protein diet [21], and high-fructose diet [77] \\
\hline $\begin{array}{l}\text { Altered short chain fatty acid profile/dysregulated } \\
\text { gut microbiota }\end{array}$ & High-fat diet [61] and high-fructose diet [78] \\
\hline Prostaglandin metabolism & Low-protein diet [39] \\
\hline
\end{tabular}


already. In part, this might be related to genetic factors. Thus, MYH9 polymorphisms [102] and APOL1 gene variants [103] have been identified as important factors contributing to the elevated risk of end stage renal disease in Americans of African ancestry compared to European ancestry. Interestingly, there is evidence from animal models that high-fat diet might upregulate MYH9 expression [104]. In a European population, variants at the UMOD locus were associated with advanced chronic kidney disease [105]. Thinking in terms of targeted nutritional interventions, this is relevant, since UMOD variants have also been linked to salt-sensitive hypertension [106]. Another aspect that needs to be considered in future studies on the preventive potential of dietary interventions is that optimal intake has not been defined for all nutrients for all age groups. For example, recent discussions about new regulatory standards on infant and follow-on formula for the European Union [107] demonstrate that there is still a need for studies defining optimal intakes of, e.g., n-3 and n- 6 polyunsaturated fatty acids in infants.

\section{Conclusions}

This review presents an overview of how maternal nutrition before and during pregnancy and lactation as well as early postnatal nutrition impact upon kidney development and long-term renal health. Adverse long-term effects have been documented for perinatal exposure to energy restriction, low-protein diet, high-fat diet, high-fructose diet, and high- and low-salt diet as well as micronutrient deficiencies. The exact renal phenotype significantly depends upon the timing of exposure. Important renal sequelae of altered macro- or micronutrient intakes include altered nephron count, blood pressure dysregulation, altered sodium handling, endothelial dysfunction, inflammation, mitochondrial dysfunction, and oxidative stress. In addition, renal prostaglandin metabolism as well as renal AMPK, mTOR, and PPAR signaling can be affected and the renin-angiotensin-aldosterone system may be dysregulated. Lately, the influence of early-life diet on gut microbiota leading to altered short chain fatty acid profiles has been discussed in the etiology of arterial hypertension. Importantly, it has been shown that postnatal nutrition significantly modifies the phenotype induced by maternal diet. Against this background, the preventive and therapeutic potential of perinatal nutritional interventions regarding kidney disease is an emerging field of research.

\section{Abbreviations}

ACE: Angiotensin-converting enzyme; Akt: Protein kinase b; AMPK: Adenosine monophosphate-activated protein kinase; ARA: Arachidonic acid; $\mathrm{AT}_{1}$ -

receptor: Angiotensin 2 receptor type 1; $\mathrm{AT}_{2}$-receptor: Angiotensin 2 receptor type 2; DGLA: Dihomo-y-linolenic acid; DHA: Docosahexaenoic acid;

EETs: Epoxyeicosatrienoic acids; ERK: Extracellular signal-regulated kinases;

FA: Fatty acid; H2S: Hydrogen sulfide; HF: High fat; mTOR: Mechanistic target

of rapamycin; n-3 FA: Omega-3 fatty acid; n-6 FA: Omega-6 fatty acid;
$\mathrm{Na}+, \mathrm{K}+-$ ATPase: Sodium-potassium adenosine triphosphatase; $\mathrm{NaCl}$ : Sodium chloride; PI3K: Phosphoinositide-3-kinase; PPAR: Peroxisome proliferatoractivated receptor; RNA: Ribonucleic acid; RAAS: Renin-angiotensinaldosterone system; SGA: Small for gestational age

\section{Acknowledgements \\ Not applicable.}

\section{Authors' contributions}

EN drafted the manuscript. JV and KDN added sections to the manuscript. All authors performed literature research, discussed content, reviewed, modified, and finally approved the manuscript.

\section{Funding}

Deutsche Forschungsgemeinschaft (DFG) NU137/3-1 to KDN and EN, NU301/ 2-1 to EN, and NU137/4-1 to KDN.

Availability of data and materials

Not applicable.

Ethics approval and consent to participate

Not applicable.

\section{Consent for publication}

Not applicable.

\section{Competing interests}

The authors declare that they have no competing interests.

Received: 22 July 2020 Accepted: 13 October 2020

Published online: 03 December 2020

\section{References}

1. Zeman FJ (1968) Effects of maternal protein restriction on the kidney of the newborn young of rats. J Nutr 94:111-116

2. Dörner G, Haller H, Leonhardt W (1973) Possible significance of pre- and or early postnatal nutrition in the pathogenesis of arteriosclerosis. Acta biologica et medica Germanica 31:K31-K35

3. Ravelli G-P, Stein ZA, Susser MW (1976) Obesity in young men after famine exposure in utero and early infancy. N Engl J Med 295:349-353

4. Painter RC, Roseboom TJ, van Montfrans GA, Bossuyt PM, Krediet RT, Osmond C, Barker DJ, Bleker OP (2005) Microalbuminuria in adults after prenatal exposure to the Dutch famine. J Am Soc Nephrol 16:189-194

5. Huang C, Guo C, Nichols C, Chen S, Martorell R (2014) Elevated levels of protein in urine in adulthood after exposure to the Chinese famine of 1959-61 during gestation and the early postnatal period. Int J Epidemiol 43:1806-1814

6. Franco Mdo C, Ponzio BF, Gomes GN, Gil FZ, Tostes R, Carvalho MH, Fortes ZB (2009) Micronutrient prenatal supplementation prevents the development of hypertension and vascular endothelial damage induced by intrauterine malnutrition. Life Sci 85:327-333

7. Vaccari B, Mesquita FF, Gontijo JA, Boer PA (2015) Fetal kidney programming by severe food restriction: effects on structure, hormonal receptor expression and urinary sodium excretion in rats. J ReninAngiotensin-Aldosterone Syst 16:33-46

8. Awazu M, Hida M (2015) Maternal nutrient restriction inhibits ureteric bud branching but does not affect the duration of nephrogenesis in rats. Ped Res 77:633-639

9. Tain YL, Hsu CN, Chan JY, Huang LT (2015) Renal Transcriptome analysis of programmed hypertension induced by maternal nutritional insults. Int J Mol Sci 16:17826-17837

10. Brennan KA, Gopalakrishnan GS, Kurlak L, Rhind SM, Kyle CE, Brooks AN, Rae MT, Olson DM, Stephenson T, Symonds ME (2005) Impact of maternal undernutrition and fetal number on glucocorticoid, growth hormone and insulin-like growth factor receptor mRNA abundance in the ovine fetal kidney. Reproduction 129:151-159

11. MacLaughlin SM, Walker SK, Kleemann DO, Tosh DN, McMillen IC (2010) Periconceptional undernutrition and being a twin each alter kidney development in the sheep fetus during early gestation. American journal of physiology Regulatory, integrative and comparative physiology 298:R692-R699

12. Sharkey D, Gardner DS, Symonds ME, Budge H (2009) Maternal nutrient restriction during early fetal kidney development attenuates the renal 
innate inflammatory response in obese young adult offspring. Am J Physiol Renal Physiol 297:F1199-F1207

13. Cox LA, Nijland MJ, Gilbert JS, Schlabritz-Loutsevitch NE, Hubbard GB, McDonald TJ, Shade RE, Nathanielsz PW (2006) Effect of 30 per cent maternal nutrient restriction from 0.16 to 0.5 gestation on fetal baboon kidney gene expression. J Physiol 572:67-85

14. Nijland MJ, Schlabritz-Loutsevitch NE, Hubbard GB, Nathanielsz PW, Cox LA (2007) Non-human primate fetal kidney transcriptome analysis indicates mammalian target of rapamycin (mTOR) is a central nutrient-responsive pathway. J Physiol 579:643-656

15. Pereira SP, Oliveira PJ, Tavares LC, Moreno AJ, Cox LA, Nathanielsz PW, Nijland MJ (2015) Effects of moderate global maternal nutrient reduction on fetal baboon renal mitochondrial gene expression at 0.9 gestation. Am J Physiol Renal Physiol 308:F1217-F1228

16. Langley-Evans SC, Welham SJ, Jackson AA (1999) Fetal exposure to a maternal low protein diet impairs nephrogenesis and promotes hypertension in the rat. Life Sci 64:965-974

17. Jones SE, Bilous RW, Flyvbjerg A, Marshall SM (2001) Intra-uterine environment influences glomerular number and the acute renal adaptation to experimental diabetes. Diabetologia 44:721-728

18. Woods LL, Ingelfinger JR, Nyengaard JR, Rasch R (2001) Maternal protein restriction suppresses the newborn renin-angiotensin system and programs adult hypertension in rats. Ped Res 49:460-467

19. Almeida JR, Mandarim-de-Lacerda CA (2005) Maternal gestational proteincalorie restriction decreases the number of glomeruli and causes glomerular hypertrophy in adult hypertensive rats. Am J Obstet Gynecol 192:945-951

20. Nwagwu MO, Cook A, Langley-Evans SC (2000) Evidence of progressive deterioration of renal function in rats exposed to a maternal low-protein diet in utero. Br J Nutr 83:79-85

21. Black MJ, Lim K, Zimanyi MA, Sampson AK, Bubb KJ, Flower RL, Parkington HC, Tare M, Denton KM (2015) Accelerated age-related decline in renal and vascular function in female rats following early-life growth restriction. Am J Physiol Reg Integr Comp Physiol 309:R1153-R1161

22. Plank C, Östreicher I, Hartner A, Marek I, Struwe FG, Amann K, Hilgers KF, Rascher W, Dötsch J (2006) Intrauterine growth retardation aggravates the course of acute mesangioproliferative glomerulonephritis in the rat. Kidney Int 70:1974-1982

23. Sahajpal V, Ashton N (2003) Renal function and angiotensin AT1 receptor expression in young rats following intrauterine exposure to a maternal lowprotein diet. Clin Sci (Lond) 104:607-614

24. McMullen S, Gardner DS, Langley-Evans SC (2004) Prenatal programming of angiotensin II type 2 receptor expression in the rat. Br J Nutr 91:133-140

25. Vehaskari VM, Stewart T, Lafont D, Soyez C, Seth D, Manning J (2004) Kidney angiotensin and angiotensin receptor expression in prenatally programmed hypertension. Am J Physiol Renal Physiol 287:F262-F267

26. Sahajpal V, Ashton N (2005) Increased glomerular angiotensin II binding in rats exposed to a maternal low protein diet in utero. J Physiol 563:193-201

27. Alwasel SH, Kaleem I, Sahajpal V, Ashton N (2010) Maternal protein restriction reduces angiotensin II AT(1) and AT(2) receptor expression in the fetal rat kidney. Kidney Blood Press Res 33:251-259

28. Cooke CL, Zhao L, Gysler S, Arany E, Regnault TR (2014) Sex-specific effects of low protein diet on in utero programming of renal G-protein coupled receptors. J Dev Orig Health Dis 5:36-44

29. Vieira-Filho LD, Cabral EV, Farias JS, Silva PA, Muzi-Filho H, Vieyra A, Paixao AD (2014) Renal molecular mechanisms underlying altered $\mathrm{Na}+$ handling and genesis of hypertension during adulthood in prenatally undernourished rats. Br J Nutr 111:1932-1944

30. Watanabe IKM, Jara ZP, Volpini RA, Franco MDC, Jung FF, Casarini DE (2018) Up-regulation of renal renin-angiotensin system and inflammatory mechanisms in the prenatal programming by low-protein diet: beneficial effect of the post-weaning losartan treatment. J Dev Orig Health Dis 9:530-535

31. Dagan A, Habib S, Gattineni J, Dwarakanath V, Baum M (2009) Prenatal programming of rat thick ascending limb chloride transport by low-protein diet and dexamethasone. Am J Physiol Reg Integr Comp Physiol 297:R93-R99

32. Luzardo R, Silva PA, Einicker-Lamas M, Ortiz-Costa S, do Carmo Mda G, Vieira-Filho LD, Paixao AD, Lara LS, Vieyra A (2011) Metabolic programming during lactation stimulates renal $\mathrm{Na}+$ transport in the adult offspring due to an early impact on local angiotensin II pathways. PLoS One 6:e21232

33. Alwasel SH, Ashton N (2012) Segmental sodium reabsorption by the renal tubule in prenatally programmed hypertension in the rat. Pediatr Nephrol 27:285-293
34. Cheng CJ, Lozano G, Baum M (2012) Prenatal programming of rat cortical collecting tubule sodium transport. Am J Physiol Renal Physiol 302:F674-F678

35. DuBois BN, Pearson J, Mahmood T, Nguyen D, Thornburg K, Cherala G (2014) Perinatal growth restriction decreases diuretic action of furosemide in adult rats. Eur J Pharmacol 728:39-47

36. Woods LL, Weeks DA, Rasch R (2004) Programming of adult blood pressure by maternal protein restriction: role of nephrogenesis. Kidney Int 65:1339-1348

37. McMullen S, Langley-Evans SC (2005) Maternal low-protein diet in rat pregnancy programs blood pressure through sex-specific mechanisms. Am J Physiol Reg Integr Comp Physiol 288:R85-R90

38. Cambonie G, Comte B, Yzydorczyk C, Ntimbane T, Germain N, Le NL, Pladys P, Gauthier C, Lahaie I, Abran D, Lavoie JC, Nuyt AM (2007) Antenatal antioxidant prevents adult hypertension, vascular dysfunction, and microvascular rarefaction associated with in utero exposure to a low-protein diet. Am J Physiol Reg Integr Comp Physiol 292:R1236-R1245

39. Sherman RC, Jackson AA, Langley-Evans SC (1999) Long-term modification of the excretion of prostaglandin $\mathrm{E}(2)$ by fetal exposure to a maternal low protein diet in the rat. Ann Nutr Metabol 43:98-106

40. Engeham S, Mdaki K, Jewell K, Austin R, Lehner AN, Langley-Evans SC (2012) Mitochondrial respiration is decreased in rat kidney following fetal exposure to a maternal low-protein diet. J Nutr Metabol 2012:989037

41. Nüsken E, Lechner F, Voggel J, Wohlfarth M, Sprenger L, Mehdiani N, Weber LT, Liebau MC, Brachvogel B, Dötsch J, Nüsken KD (2020) Altered molecular signatures during kidney development after intrauterine growth restriction of different origins. J Mol Med 98:395-407

42. Manning J, Vehaskari VM (2005) Postnatal modulation of prenatally programmed hypertension by dietary Na and ACE inhibition. Am J Physiol Reg Integr Comp Physiol 288:R80-R84

43. Lozano G, Elmaghrabi A, Salley J, Siddique K, Gattineni J, Baum M (2015) Effect of prenatal programming and postnatal rearing on glomerular filtration rate in adult rats. Am J Physiol Renal Physiol 308:F411-F419

44. Siddique K, Guzman GL, Gattineni J, Baum M (2014) Effect of postnatal maternal protein intake on prenatal programming of hypertension. Reproduct Sci (thousand oaks, Calif) 21:1499-1507

45. Harrison M, Langley-Evans SC (2009) Intergenerational programming of impaired nephrogenesis and hypertension in rats following maternal protein restriction during pregnancy. Br J Nutr 101:1020-1030

46. Hoppe CC, Evans RG, Bertram JF, Moritz KM (2007) Effects of dietary protein restriction on nephron number in the mouse. Am J Physiol Reg Integr Comp Physiol 292:R1768-R1774

47. Hoppe CC, Evans RG, Moritz KM, Cullen-McEwen LA, Fitzgerald SM, Dowling J, Bertram JF (2007) Combined prenatal and postnatal protein restriction influences adult kidney structure, function, and arterial pressure. Am J Physiol Reg Integr Comp Physiol 292:R462-R469

48. Lloyd $\sqcup$, Foster T, Rhodes P, Rhind SM, Gardner DS (2012) Protein-energy malnutrition during early gestation in sheep blunts fetal renal vascular and nephron development and compromises adult renal function. J Physiol 590:377-393

49. Dunford LJ, Sinclair KD, Kwong WY, Sturrock C, Clifford BL, Giles TC, Gardner DS (2014) Maternal protein-energy malnutrition during early pregnancy in sheep impacts the fetal ornithine cycle to reduce fetal kidney microvascular development. FASEB J 28:4880-4892

50. Zimanyi MA, Bertram JF, Black MJ (2002) Nephron number and blood pressure in rat offspring with maternal high-protein diet. Pediatr Nephrol 17:1000-1004

51. Huang X, Lindholm B, Stenvinkel P, Carrero JJ (2013) Dietary fat modification in patients with chronic kidney disease: n-3 fatty acids and beyond. J Nephrol 26:960-974

52. Croft KD, Beilin LJ, Vandongen R, Mathews E (1984) Dietary modification of fatty acid and prostaglandin synthesis in the rat. Effect of variations in the level of dietary fat. Biochim Biophys Acta 795:196-207

53. Calvo-Rubio M, Buron MI, Lopez-Lluch G, Navas P, de Cabo R, Ramsey JJ, Villalba JM, Gonzalez-Reyes JA (2016) Dietary fat composition influences glomerular and proximal convoluted tubule cell structure and autophagic processes in kidneys from calorie-restricted mice. Aging Cell 15:477-487

54. Shamseldeen AM, Ali Eshra M, Ahmed Rashed L, Fathy Amer M, Elham Fares A, Samir Kamar S (2019) Omega-3 attenuates high fat diet-induced kidney injury of female rats and renal programming of their offsprings. Arch Physiol Biochem 125:367-377

55. Jackson CM, Alexander BT, Roach L, Haggerty D, Marbury DC, Hutchens ZM, Flynn ER, Maric-Bilkan C (2012) Exposure to maternal overnutrition and a highfat diet during early postnatal development increases susceptibility to renal and metabolic injury later in life. Am J Physiol Renal Physiol 302:F774-F783 
56. Guberman C, Jellyman JK, Han G, Ross MG, Desai M (2013) Maternal high-fat diet programs rat offspring hypertension and activates the adipose renin-angiotensin system. American journal of obstetrics and gynecology 209:262.e261-268.

57. Glastras SJ, Chen H, Tsang M, Teh R, McGrath RT, Zaky A, Chen J, Wong MG, Pollock CA, Saad S (2017) The renal consequences of maternal obesity in offspring are overwhelmed by postnatal high fat diet. PLoS One 12:e0172644

58. Tain YL, Lin YJ, Sheen JM, Yu HR, Tiao MM, Chen CC, Tsai CC, Huang LT, Hsu CN (2017) High fat diets sex-specifically affect the renal transcriptome and program obesity, kidney injury, and hypertension in the offspring. Nutrients 9:357

59. Hokke S, Puelles VG, Armitage JA, Fong K, Bertram JF, Cullen-McEwen LA (2016) Maternal fat feeding augments offspring nephron endowment in mice. PLoS One 11:e0161578

60. Armitage JA, Lakasing L, Taylor PD, Balachandran AA, Jensen RI, Dekou V, Ashton N, Nyengaard JR, Poston L (2005) Developmental programming of aortic and renal structure in offspring of rats fed fat-rich diets in pregnancy. J Physiol 565:171-184

61. Hsu CN, Hou CY, Lee CT, Chan JYH, Tain YL (2019) The interplay between maternal and post-weaning high-fat diet and gut microbiota in the developmental programming of hypertension. Nutrients 11:1982

62. Tain YL, Lin YJ, Sheen JM, Lin IC, Yu HR, Huang LT, Hsu CN (2017) Resveratrol prevents the combined maternal plus postweaning high-fatdiets-induced hypertension in male offspring. J Nutr Biochem 48:120-127

63. Nüsken E, Turnwald EM, Fink G, Voggel J, Yosy C, Kretschmer T, Handwerk M, Wohlfarth M, Weber LT, Hucklenbruch-Rother E, Dötsch J, Nüsken KD, Appel S (2019) Maternal high fat diet and in-utero metformin exposure significantly impact upon the fetal renal proteome of male mice. J Clin Med 8:663

64. Kasper P, Vohlen C, Dinger K, Mohr J, Hucklenbruch-Rother E, Janoschek R Koth J, Matthes J, Appel S, Dotsch J, Alejandre Alcazar MA (2017) Renal metabolic programming is linked to the dynamic regulation of a leptinKlf15 axis and Akt/AMPKalpha signaling in male offspring of obese dams. Endocrinology 158:3399-3415

65. Nguyen LT, Mak CH, Chen H, Zaky AA, Wong MG, Pollock CA, Saad S (2019) SIRT1 attenuates kidney disorders in male offspring due to maternal highfat diet. Nutrients 11:146

66. Chowdhury SS, Lecomte V, Erlich JH, Maloney CA, Morris MJ (2016) Paternal high fat diet in rats leads to renal accumulation of lipid and tubular changes in adult offspring. Nutrients 8:521

67. van Eijsden M, Hornstra G, van der Wal MF, Vrijkotte TG, Bonsel GJ (2008) Maternal $n-3, n-6$, and trans fatty acid profile early in pregnancy and term birth weight: a prospective cohort study. Am J Clin Nutr 87:887-895

68. Meher A, Randhir K, Mehendale S, Wagh G, Joshi S (2016) Maternal fatty acids and their association with birth outcome: a prospective study. PLoS One 11:e0147359

69. Hallan S, Euser AM, Irgens LM, Finken MJ, Holmen J, Dekker FW (2008) Effect of intrauterine growth restriction on kidney function at young adult age: the Nord Trondelag health (HUNT 2) study. Am J Kidney Dis 51:10-20

70. Zidar N, Cavic MA, Kenda RB, Koselj M, Ferluga D (1998) Effect of intrauterine growth retardation on the clinical course and prognosis of $\lg A$ glomerulonephritis in children. Nephron 79:28-32

71. Gibson RA, Neumann MA, Makrides M (1997) Effect of increasing breast milk docosahexaenoic acid on plasma and erythrocyte phospholipid fatty acids and neural indices of exclusively breast fed infants. Eur J Clin Nutr 51:578-584

72. Fidler N, Sauerwald T, Pohl A, Demmelmair H, Koletzko B (2000) Docosahexaenoic acid transfer into human milk after dietary supplementation: a randomized clinical trial. J Lipid Res 41:1376-1383

73. Huang YS, Wainwright PE, Redden PR, Mills DE, Bulman-Fleming B, Horrobin DF (1992) Effect of maternal dietary fats with variable $n-3 / n-6$ ratios on tissue fatty acid composition in suckling mice. Lipids 27:104-110

74. Cadenas C, Vosbeck S, Hein EM, Hellwig B, Langer A, Hayen $H_{\text {, }}$ Franckenstein D, Büttner B, Hammad S, Marchan R, Hermes M, Selinski S, Rahnenführer J, Peksel B, Török Z, Vígh L, Hengstler JG (2012)

Glycerophospholipid profile in oncogene-induced senescence. Biochim Biophys Acta 1821:1256-1268

75. Flynn ER, Alexander BT, Lee J, Hutchens ZM Jr, Maric-Bilkan C (2013) Highfat/fructose feeding during prenatal and postnatal development in female rats increases susceptibility to renal and metabolic injury later in life. Am J Physiol Reg Integr Comp Physiol 304:R278-R285

76. Yamada-Obara N, Yamagishi SI, Taguchi K, Kaida Y, Yokoro M, Nakayama Y, Ando R, Asanuma K, Matsui T, Ueda S, Okuda S, Fukami K (2016) Maternal exposure to high-fat and high-fructose diet evokes hypoadiponectinemia and kidney injury in rat offspring. Clin Exp Nephrol 20:853-861
77. Tain YL, Lee WC, Wu KLH, Leu S, Chan JYH (2016) Targeting arachidonic acid pathway to prevent programmed hypertension in maternal fructosefed male adult rat offspring. J Nutr Biochem 38:86-92

78. Hsu CN, Lin YJ, Hou CY, Tain YL (2018) Maternal administration of probiotic or prebiotic prevents male adult rat offspring against developmental programming of hypertension induced by high-fructose consumption in pregnancy and lactation. Nutrients 10:1229

79. Vaidya A, Saville N, Shrestha BP, Costello AM, Manandhar DS, Osrin D (2008) Effects of antenatal multiple micronutrient supplementation on children's weight and size at 2 years of age in Nepal: follow-up of a double-blind randomised controlled trial. Lancet 371:492-499

80. Stewart CP, Christian P, Schulze KJ, Leclerq SC, West KP Jr, Khatry SK (2009) Antenatal micronutrient supplementation reduces metabolic syndrome in 6- to 8-year-old children in rural Nepal. J Nutr 139:1575-1581

81. Hawkesworth S, Wagatsuma Y, Kahn Al, Hawlader MD, Fulford AJ, Arifeen SE, Persson LA, Moore SE (2013) Combined food and micronutrient supplements during pregnancy have limited impact on child blood pressure and kidney function in rural Bangladesh. J Nutr 143:728-734

82. El-Khashab EK, Hamdy AM, Maher KM, Fouad MA, Abbas GZ (2013) Effect of matemal vitamin a deficiency during pregnancy on neonatal kidney size. J Perinat Med 41:199-203

83. Lelievre-Pegorier M, Vilar J, Ferrier ML, Moreau E, Freund N, Gilbert T, MerletBenichou C (1998) Mild vitamin a deficiency leads to inborn nephron deficit in the rat. Kidney Int 54:1455-1462

84. Lisle SJ, Lewis RM, Petry CJ, Ozanne SE, Hales CN, Forhead AJ (2003) Effect of maternal iron restriction during pregnancy on renal morphology in the adult rat offspring. Br J Nutr 90:33-39

85. Sun MY, Woolley JC, Blohowiak SE, Smith ZR, Siddappa AM, Magness RR, Kling PJ (2016) Dietary-induced gestational iron deficiency inhibits postnatal tissue iron delivery and postpones the cessation of active nephrogenesis in rats. Reprod Fertil Dev 29:855-866

86. Woodman AG, Mah R, Keddie DL, Noble RMN, Holody CD, Panahi S, Gragasin FS, Lemieux H, Bourque SL (2020) Perinatal iron deficiency and a high salt diet cause long-term kidney mitochondrial dysfunction and oxidative stress. Cardiovasc Res 116:183-192

87. Tomat AL, Inserra F, Veiras L, Vallone MC, Balaszczuk AM, Costa MA, Arranz C (2008) Moderate zinc restriction during fetal and postnatal growth of rats: effects on adult arterial blood pressure and kidney. Am J Physiol Reg Integr Comp Physiol 295:R543-R549

88. Tomat AL, Veiras LC, Aguirre S, Fasoli H, Elesgaray R, Caniffi C, Costa MA, Arranz CT (2013) Mild zinc deficiency in male and female rats: early postnatal alterations in renal nitric oxide system and morphology. Nutrition (Burbank, Los Angeles County, Calif) 29:568-573.

89. Koleganova N, Piecha G, Ritz E, Becker LE, Muller A, Weckbach M, Nyengaard JR, Schirmacher P, Gross-Weissmann ML (2011) Both high and low maternal salt intake in pregnancy alter kidney development in the offspring. Am J Physiol Renal Physiol 301:F344-F354

90. Gray C, Al-Dujaili EA, Sparrow AJ, Gardiner SM, Craigon J, Welham SJ, Gardner DS (2013) Excess maternal salt intake produces sex-specific hypertension in offspring: putative roles for kidney and gastrointestinal sodium handling. PLoS One 8:e72682

91. Ramos DR, Costa NL, Jang KL, Oliveira IB, da Silva AA, Heimann JC, Furukawa LN (2012) Maternal high-sodium intake alters the responsiveness of the renin-angiotensin system in adult offspring. Life Sci 90:785-792

92. Mao C, Liu R, Bo L, Chen N, Li S, Xia S, Chen J, Li D, Zhang L, Xu Z (2013) High-salt diets during pregnancy affected fetal and offspring renal reninangiotensin system. J Endocrinol 218:61-73

93. Cabral EV, Vieira-Filho LD, Silva PA, Nascimento WS, Aires RS, Oliveira FS, Luzardo R, Vieyra A, Paixao AD (2012) Perinatal Na+ overload programs raised renal proximal $\mathrm{Na}+$ transport and enalapril-sensitive alterations of Ang II signaling pathways during adulthood. PLoS One 7:e43791

94. Chadwick MA, Vercoe PE, Williams IH, Revell DK (2009) Dietary exposure of pregnant ewes to salt dictates how their offspring respond to salt. Physiol Behav 97:437-445

95. Chadwick MA, Williams IH, Vercoe PE, Revell DK (2009) Feeding pregnant ewes a high-salt diet or saltbush suppresses their offspring's postnatal renin activity. Animal 3:972-979

96. Jackson AA, Dunn RL, Marchand MC, Langley-Evans SC (2002) Increased systolic blood pressure in rats induced by a maternal low-protein diet is reversed by dietary supplementation with glycine. Clin Sci (Lond) 103:633-639

97. Makrakis J, Zimanyi MA, Black MJ (2007) Retinoic acid enhances nephron endowment in rats exposed to maternal protein restriction. Pediatr Nephrol 22:1861-1867 
98. Sutherland MR, Gubhaju L, Yoder BA, Stahlman MT, Black MJ (2009) The effects of postnatal retinoic acid administration on nephron endowment in the preterm baboon kidney. Ped Res 65:397-402

99. Luyckx VA, Brenner BM (2015) Birth weight, malnutrition and kidneyassociated outcomes--a global concern. Nat Rev Nephrol 11:135-149

100. Bakker H, Kooijman MN, van der Heijden AJ, Hofman A, Franco OH, Taal HR, Jaddoe WW (2014) Kidney size and function in a multi-ethnic populationbased cohort of school-age children. Pediatr Nephrol 29:1589-1598

101. Thomas C, Nightingale CM, Donin AS, Rudnicka AR, Owen CG, Cook DG, Whincup PH (2012) Ethnic and socioeconomic influences on childhood blood pressure: the child heart and health study in England. J Hypertens 30: 2090-2097

102. Bostrom MA, Freedman BI (2010) The spectrum of MYH9-associated nephropathy. Clin J Am Soc Nephrol 5:1107-1113

103. Gutiérrez OM, Judd SE, Irvin MR, Zhi D, Limdi N, Palmer ND, Rich SS, Sale MM, Freedman BI (2016) APOL1 nephropathy risk variants are associated with altered high-density lipoprotein profiles in African Americans. Nephrol Dialysis Transplant 31:602-608

104. Ichimura K, Kawashima Y, Nakamura T, Powell R, Hidoh Y, Terai S, Sakaida I, Kodera Y, Tsuji T, Ma JX, Sakai T, Matsumoto H, Obara T (2013) Medaka fish, Oryzias latipes, as a model for human obesity-related glomerulopathy. Biochem Biophys Res Commun 431:712-717

105. Wunnenburger S, Schultheiss UT, Walz G, Hausknecht B, Ekici AB, Kronenberg F, Eckardt KU, Köttgen A, Wuttke M (2017) Associations between genetic risk variants for kidney diseases and kidney disease etiology. Sci Rep 7:13944

106. Trudu M, Janas S, Lanzani C, Debaix H, Schaeffer C, Ikehata M, Citterio L, Demaretz S, Trevisani F, Ristagno G, Glaudemans B, Laghmani K, Dell'Antonio G, Loffing J, Rastaldi MP, Manunta P, Devuyst O, Rampoldi L (2013) Common noncoding UMOD gene variants induce salt-sensitive hypertension and kidney damage by increasing uromodulin expression. Nat Med 19:1655-1660

107. Koletzko B, Bergmann K, Brenna JT, Calder PC, Campoy C, Clandinin MT, Colombo J, Daly M, Decsi T, Demmelmair H, Domellöf M, FidlerMis N, Gonzalez-Casanova I, van Goudoever JB, Hadjipanayis A, Hernell O, Lapillonne A, Mader S, Martin CR, Matthäus V, Ramakrishan U, Smuts CM, Strain SJJ, Tanjung C, Tounian P, Carlson SE (2020) Should formula for infants provide arachidonic acid along with DHA? A position paper of the European academy of Paediatrics and the Child Health Foundation. Am J Clin Nutr 111:10-16

\section{Publisher's Note}

Springer Nature remains neutral with regard to jurisdictional claims in published maps and institutional affiliations.

\section{Submit your manuscript to a SpringerOpen ${ }^{\circ}$ journal and benefit from:}

- Convenient online submission

- Rigorous peer review

- Open access: articles freely available online

- High visibility within the field

- Retaining the copyright to your article

Submit your next manuscript at $\boldsymbol{\nabla}$ springeropen.com 